\title{
The effect of intracavernosal alprostadil use in erectile dysfunction second line treatment on sexual functions
}

\author{
Erektil disfonksiyon 2.basamak tedavide intrakavernozal alprostadil kullanımının cinsel \\ fonksiyonlar üzerine etkisi
}

\author{
Hakan Tașkapu ', Mehmet Giray Sönmez ', Muzaffer Tansel Kılınç', Nurullah Altınkaya ', Arif Aydın ', Mehmet Balasar ${ }^{1}$ \\ 1 Necmettin Erbakan University, Meram Medical Faculty, Department of Urology, Konya, Turkey
}

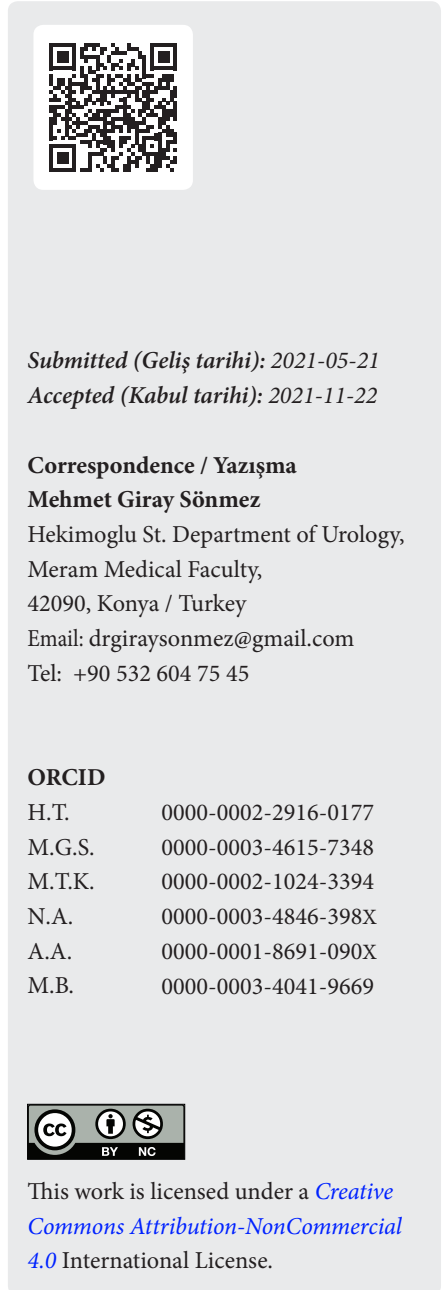

\begin{abstract}
Özet
Amaç: Bu çalışmada erektil disfonksiyon nedeniyle ikinci basamak tedavide intrakavernozal alprostadil uygulanarak tedavi edilen hastalarda tedavinin 15 soruluk Uluslararası Erektil Fonksiyon Endeksi (IIEF-15) anketi ile ölçülen cinsel fonksiyonlar üzerine etkisi araştırılmıştır.

Gereç ve Yöntemler: Haziran 2018 - Ekim 2019 arasında erektil disfonksiyon nedeniyle tedavi gören, birinci basamak tedavi modalitelerinden yetersiz yanıt alınan, ikinci basamak tedavide intrakavernozal alprostadil uygulanan ve 12 haftadan daha uzun süre tedaviye devam eden hastaların verileri retrospektif olarak incelenerek 21 hasta çalışmaya dahil edildi. Hastaların yaşları, ek hastalıkları, ilaç kullanım süreleri, ilaca bağlı yan etkiler, uygulama öncesi penil Doppler ultrasonografi (USG) parametreleri ve ilaç kullanımı öncesi ve 12 hafta sonrası ereksiyon fonksiyonları IIEF-15 formu ile değerlendirildi. İntrakavernozal alprostadil'e $5 \mu \mathrm{g}$ dozdan başlandıktan sonra doz titrasyonu neticesinde $10 \mu \mathrm{g}$ dozunda devam edildi.

Bulgular: Tedavi öncesi yapılan penil Doppler USG de hastaların ortalama peak sistolik akım hızı (PS) değeri $24,4 \pm 15,1 \mathrm{~cm} / \mathrm{sn}$, ortalama end diastolik akım hızı (ED) değeri $4,3 \pm 4,5 \mathrm{~cm} / \mathrm{sn}$ olarak ölçüldü. IIEF skorları 12. haftada ölçülmesine

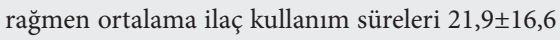
hafta olarak ölçüldü. Erektil Fonksiyon Skoru uygulama öncesi $9.2 \pm 5.3$ iken uygulama sonras1 $20.33 \pm 6.2$ olarak tespit edildi. Orgazmik İşlev Skoru uygulama öncesi $3,2 \pm 2,5$, uygulama sonrası
\end{abstract}

\section{Abstract}

Objective: In patients treated through the application of intracavernosal alprostadil in second-line treatment due to erectile dysfunction, the effect of the treatment on sexual functions measured with a 15-question International Index of Erectile Function (IIEF-15) questionnaire was investigated in this study.

Material and Methods: Twenty-one patients treated due to erectile dysfunction between June 2018-October 2019, taking inadequate response from first-line treatment modalities, were applied intracavernosal alprostadil in second-line treatment and continued it for more than 12 weeks were included in the study, retrospectively. Ages, comorbid diseases, drug usage duration, drug-related side effects, penile Doppler ultrasonography (USG) parameters before application and the erection functions before and 12 weeks after drug use were evaluated with IIEF-15 form for the patients. Intracavernosal alprostadil was started with a dose of $5 \mu \mathrm{g}$ and was continued with a dose of $10 \mu \mathrm{g}$ as the result of dose titration.

Results: The mean peak systolic blood flow velocity (PS) value of the patients was $24.4 \pm 15.1$ $\mathrm{cm} / \mathrm{sec}$, and the mean end-diastolic flow velocity (ED) value was measured as $4.3 \pm 4.5 \mathrm{~cm} / \mathrm{sec}$ based on the pre-treatment penile Doppler USG. Although the IIEF scores were measured in the 12 th week, mean drug usage durations were measured as $21.9 \pm 16.6$ weeks. Erectile Function Score was $9.2 \pm 5.3$ before application; it was detected as $20.33 \pm 6.2$ after the application. Orgasmic Function Score was $3.2 \pm 2.5$ before application; it was

Cite As: Taşkapu H, Sönmez MG, Kılınç MT et al. The effect of intracavernosal alprostadil use in erectile dysfunction second line treatment on sexual functions New J Urol. 2022; 17(1):1-5. DOI: 10.33719/yud.2022;17-1-940774

The study was approved by Ethical Committee of Necmettin Erbakan University Meram Faculty of Medicine (Approval No: 2020/2494). All research was performed in accordance with relevant guidelines/regulations, and informed consent was obtained from all participants. 
ise 7,5 $\pm 2,4$ olarak tespit edildi. Cinsel İstek Skoru uygulama öncesi 3,72 $\pm 1,48$, uygulama sonrası $8,9 \pm 1,4$ olarak tespit edildi. Cinsel Memnuniyet Skoru uygulama öncesi 3,7 $\pm 2,8$, uygulama sonrası ise $9,1 \pm 2,7$ olarak tespit edildi. Genel Memnuniyet Skoru uygulama öncesi $4 \pm 1.7$ iken uygulama sonrası $8.1 \pm 1.7$ olarak tespit edildi (Tüm parametreler $\mathrm{p}<0,001)$.

Sonuç: Erektil disfonksiyon ikinci basamak tedavisinde kullanılan intrakavernozal alprostadil tedavisi IIEF-15 parametreleri ile ölçülebilen cinsel parametrelerde düzelme sağlayan, tolere edilebilir yan etki profiline sahip, kostefektif ve etkin bir tedavi yöntemidir.

Anahtar Kelimeler: Alprostadil, erektil disfonksiyon, intrakavernozal tedavi. detected as $7.5 \pm 2.4$ after the application. Sexual Desire Score was $3.72 \pm 1.48$ before application; it was detected as $8.9 \pm 1.4$ after the application. Intercourse Satisfaction Score was $3.7 \pm 2.8$ before application; it was detected as $9.1 \pm 2.7$ after the application. Overall Satisfaction Score was $4 \pm 1.7$ before application; it was detected as $8.1 \pm 1.7$ after the application (All parameters $\mathrm{p}<0.001$ ).

Conclusion: Intracavernosal alprostadil treatment used in erectile dysfunction second-line treatment is a cost-effective and efficient treatment method with a tolerable side effect profile and provides recovery in sexual parameters that can be measured with IIEF-15 parameters.

Keywords: Alprostadil, erectile dysfunction, intracavernosal treatment.

\section{INTRODUCTION}

Erectile dysfunction (ED) is defined as the inability to acquire penile hardness necessary for successful sexual intercourse and continue it even if it is acquired (1).

Different therapeutic agents were developed for ED treatment, and their effect mechanism depends on the understanding of erection physiology. Lifestyle changes and phosphodiesterase type 5 inhibitors (PDE5 inhibitors) as first-line treatment options may be used in ED treatment. PDE5 inhibitors are non-invasive, are generally well-tolerated and efficient in most males. Intracavernosal injections (ICUs) such as alprostadil and Papaverine can be used in $25-50 \%$ of patients who are recalcitrant to the treatment and contraindicate PDE5 inhibitors (2-4).

In patients inadequately responding to first-line treatment modalities in erectile dysfunction treatment and targeted to take early rehabilitation after prostatectomy, intracavernosal alprostadil can be used in second-line treatment $(2,3)$. It was observed to be effective in more than $70 \%$ of the patients in the general ED population, $94 \%$ of the patients could have sexual intercourse after injection, and approximately $90 \%$ of the partners were satisfied due to the drug $(4,5)$. International Index of Erectile Function (IIEF-15) questionnaire is a standard questioning form is used to evaluate functions including erectile function, orgasm function, sexual desire, sexual intercourse adequacy, and general satisfaction (2-4).

The effect of treatment on sexual functions measured with IIEF-15 was investigated in patients evaluated for erectile dysfunction, did not benefit from first-line treatment methods, and was treated through intracavernosal alprostadil application in second-line treatment.

\section{MATERIAL AND METHODS}

Patients treated in the Urology department of a university hospital due to erectile dysfunction between June 2018 and October 2019 had an inadequate response from first-line treatment modalities and were applied intracavernosal alprostadil in second-line treatment were retrospectively examined. Twenty-one patients who continued the treatment for more than 12 weeks were included in the study. The glucose-lipid and hormone profiles were evaluated. Patients with vascular ED demonstrated by penile Doppler ultrasonography (USG) were included in the study. None of the patients had hormonal ED.

Failure to respond to Tadalafil $5 \mathrm{mg}$ daily for at least 12 weeks was defined as oral therapy failure.

Ages, comorbid diseases, drug usage duration, drug-related side effects, penile Doppler USG parameters before application, and the erection functions before and 12 weeks after drug use were evaluated with IIEF-15 form for the patients.

Doppler USG was performed on all patients with $60 \mathrm{mg}$ Papaverine Hcl. The drug was applied by intracavernosal injection from the $1 / 3$ zone of the penis proximally with a 26 -gauge and 2 - $\mathrm{ml}$ injector. Then, in the fifth, tenth, fifteenth, and twentieth minutes, arterial and venous penis flows were evaluated. Measurements were made with Siemens Acuson S2000, 9 Mhz linear probes. 


\section{Treatment Protocol}

Alprostadil (Jectera ${ }^{\oplus}$, Vem Pharmaceuticals, İstanbul, Turkey) application was applied using a 0.5 inch, 27 to 30 gauge needle, avoiding visible veins and injecting in the dorsolateral direction of the proximal third of the penis. alprostadil was started with a dose of $5 \mu \mathrm{g}$ and was continued with a dose of $10 \mu \mathrm{g}$ as the result of dose titration in all patients. IIEF-15 scores before and after the application were compared.

\section{Statistical Analysis}

Statistical analysis was performed with SPSS v.23.0 statistical software (SPSS, Inc., Chicago, IL, USA). Quantitative data were given as mean \pm SD. The Wilcoxon signed Rank Test was used to analyze the relationship between IIEF-15 scores before and after treatment. Kolmogorov-Smirnov test was used to evaluate the normal distribution of the data. The p-value below 0.05 was considered statistically significant.

\section{RESULTS}

The mean age of 21 patients included in the study was $53.8 \pm 11.6$ years. Twelve patients $(57.1 \%)$ had a story of diabetes mellitus (DM), and 4 (19\%) had pelvic organ cancer surgery stories. Two patients had a story of radical prostatectomy, one patient had rectum surgery, and one had a radical cystectomy story. Five patients $(23.8 \%)$ did not have any comorbidities.

Fasting Glucose levels were $91.6 \pm 20.3 \mathrm{mg} / \mathrm{dL}$. Total
Testosterone levels were $471.2 \pm 127.5 \mathrm{ng} / \mathrm{dl}$. The Follicle-stimulating hormone (FSH) levels were $8.2 \pm 3.6$ $\mathrm{mIU} / \mathrm{mL}$, while the Luteinizing hormone (LH) levels were $6.2 \pm 2.4 \mathrm{mIU} / \mathrm{mL}$.

The mean peak systolic blood flow velocity (PS) of the patients was measured as $24.4 \pm 15.1 \mathrm{~cm} / \mathrm{sec}$, and the mean end-diastolic flow velocity (ED) was measured as $4.3 \pm 4.5 \mathrm{~cm} / \mathrm{sec}$ based on the pre-treatment penile Doppler USG.

Although the IIEF-15 sub-scores were measured in the 12th week, mean drug usage durations were measured as $21.9 \pm 16.6$ weeks. General parameters of the patients are available in Table 1.

Two out of 21 patients (9.5\%) had penile pain in the application zone, and 2 had (9.5\%) priapism after application, and 17 patients (81\%) did not have any side effects.

Erectile Function Score was 9.2 \pm 5.3 before application; it was detected as $20.33 \pm 6.2$ after the application. Orgasmic Function Score was $3.2 \pm 2.5$ before application; it was detected as $7.5 \pm 2.4$ after the application. Sexual Desire Score was 3.72 \pm 1.48 before application; it was detected as $8.9 \pm 1.4$ after the application. Intercourse Satisfaction Score was 3.7 \pm 2.8 before application; it was detected as $9.1 \pm 2.7$ after the application. Overall Satisfaction Score was $4 \pm 1.7$ before application. It was detected as $8.1 \pm 1.7$ after the application (All parameters $\mathrm{p}<0.001$ ). Scores of IIEF-15 sub-parameters are available in Table 2.

Table 1. General details of the patients

\begin{tabular}{ll}
\hline Number $(\mathbf{n})$ & 21 \\
\hline Age (years) (mean \pm SD) & $53.8 \pm 11.6$ \\
\hline Comorbidity n (\%) & $12(57.1 \%)$ \\
DM & $4(19 \%)$ \\
Pelvic Organ Surgery & $91.6 \pm 20.3$ \\
\hline Fasting Glucose Levels (mg/dL) (mean \pm SD) & $471.2 \pm 127.5$ \\
\hline Total Testosterone (ng/dl) (mean \pm SD) & $8.2 \pm 3.6$ \\
FSH (mIU/mL) (mean \pm SD) & $6.2 \pm 2.4$ \\
LH (mIU/mL) (mean \pm SD) & \\
\hline Penile Doppler USG (cm/sec) & $24.4 \pm 15.1$ \\
Peak systolic velocity (PS) & $4.3 \pm 4.5$ \\
End diastolic velocity $($ ED) & \\
\hline Side Effect $\%)$ & $2(9.5 \%)$ \\
Penile Pain & $2(9.5 \%)$ \\
Priapism & $21.9 \pm 16.6$ \\
\hline Alprostadil Usage Duration (weeks) & \\
\hline
\end{tabular}


Table 2. Pre-treatment and post-treatment IIEF-15 parameters

\begin{tabular}{llll}
\hline & Pre-Treatment & Post- Treatment & p \\
\hline Erectile Function Score (IIEF-15) & $9.2 \pm 5.3$ & $20.33 \pm 6.2$ & $\mathrm{p}<0.001$ \\
Orgasmic Function Score (IIEF-15) & $3.2 \pm 2.5$ & $7.5 \pm 2.4$ & $\mathrm{p}<0.001$ \\
Sexual Desire Score (IIEF-15) & $3.72 \pm 1.48$ & $8.9 \pm 1.4$ & $\mathrm{p}<0.001$ \\
Intercourse Satisfaction Score (IIEF-15) & $3.7 \pm 2.8$ & $9.1 \pm 2.7$ & $\mathrm{p}<0.001$ \\
Overall Satisfaction Score (IIEF-15) & $4 \pm 1.7$ & $8.1 \pm 1.7$ & $\mathrm{p}<0.001$ \\
\hline
\end{tabular}

\section{DISCUSSION}

Alprostadil is a synthetic form of prostaglandin E1 binding to the specific receptors on flat muscle cells and causing tissue relaxation through the second messenger system by activating intracellular adenylate cyclase (6).

In patients with an inadequate response to oral treatment in erectile dysfunction treatment, it can be applied with a success ratio reaching $80 \%$ in erectile dysfunction caused by neurogenic, vasculogenic, and psychogenic causes in second-line treatment $(5,7)$.

Its use is contraindicated in patients with psychological disease, priapism story, severe coagulopathy or unstable cardiovascular disease story, decreased hand skill although the partner is trainable in injection technique and use monoamine oxidase inhibitors (8). We included patients without a condition forming contraindication for intracavernosal alprostadil use in our study.

Alprostadil provides complete erection in $70-80 \%$ of ED patients at doses between 10 and $20 \mu \mathrm{g}$ (9). Erection was provided in all patients in our study after starting alprostadil with a dose of $5 \mu \mathrm{g}$ and continuing with $10 \mu \mathrm{g}$ following the clinic and dose titration application, and this dose was continued.

Approved questionnaires are suggested to evaluate the disease severity, measure treatment efficiency, and future lead treatment in patients with erectile dysfunction (10). We evaluated our patients with the International Index of Erectile Functions (IIEF-15) before and after the treatment in our study. In the study by Linet et al., $87 \%$ of the males and $86 \%$ of their partners were satisfied with their sexual activity after intracavernosal alprostadil injection. Similar to this data, we detected a statistically significant recovery in all IIEF parameters in all our patients after the treatment.
Treatment's most common side effects are a pain in the injection zone in $11 \%$, hematoma in $1.5 \%$, and lengthened erection or priapism in 1-5\% (5). During the mean drug usage duration of $21.9 \pm 16.6$ weeks, penile pain was detected in the injection zone in $9.5 \%$, and priapism was observed in $9.5 \%$ of the patients in our study. These values are parallel to literature.

The advantages of alprostadil compared to other intracavernosal applied agents are lengthened erection, lower systemic side effects, and penile fibrosis incidence. To our patients not benefiting from first-line treatment in our study, we recommended alprostadil treatment due to its low side effect profile and high efficiency. We acquired a statistically significant response in all sexual function parameters in all patients at the end of 12-week treatment. Penile pain and priapism were the most common side effects in our patients. The monthly treatment cost is approximately 26 dollars.

In addition, it was also observed that the treatment lasted up to 21 weeks in patients using intracavernosal alprostadil. This condition shows that the drug is tolerable.

As a result, intracavernosal alprostadil treatment is a tolerable, cost-effective, and efficient treatment method in second-line treatment.

\section{CONCLUSION}

Intracavernosal alprostadil treatment used in erectile dysfunction second line treatment is a cost-effective and efficient treatment method with a tolerable side effect profile and provides a recovery in sexual parameters with can be measured with IIEF-15 parameters. 


\section{Conflict of interest}

The authors declare to have no conflicts of interest.

\section{Financial Disclosure}

The authors declared that this study has received no financial support.

\section{Informed Consent}

Informed consent was obtained from all individual participants included in the study.

\section{Ethical Approval}

The study was approved by Ethical Committee of Necmettin Erbakan University Meram Faculty of Medicine (Approval Number: 2020/2494) and written informed consent was received from all participants. The study protocol conformed to the ethical guidelines of the Helsinki Declaration.

\section{Author Contributions}

Conception and design; HT, MGS, MTK, Data acquisition; HT, MGS, MTK, NA, AA, MB, Data analysis and interpretation; HT, MGS, MTK, NA, AA, MB, Drafting the manuscript; HT, MGS, MTK, Critical revision of the manuscript for scientific and factual content; HT, MGS, MTK, NA, AA, MB, Statistical analysis; MGS, Supervision; HT.

\section{REFERENCES}

1. Shamloul R, Ghanem H. Erectile dysfunction. Lancet. 2013;381(9861):153-165.

2. Hatzimouratidis K, Salonia A, Adaikan G, et al. Pharmacotherapy for Erectile Dysfunction: Recommendations From the Fourth International Consultation for Sexual Medicine (ICSM 2015). J Sex Med. 2016;13(4):465-488.

3. Yiou R, Ebrahiminia V, Mouracade P, Lingombet O, Abbou C. Sexual quality of life in women partnered with men using intracavernous alprostadil injections after radical prostatectomy. J Sex Med. 2013;10(5):1355-1362.

4. Eardley I, Donatucci C, Corbin J, et al. Pharmacotherapy for erectile dysfunction. J Sex Med. 2010; 7(1-2):524-540.

5. Linet OO, Ogrinc FG. Efficacy and safety of intracavernosal alprostadil in men with erectile dysfunction. $\mathrm{N}$ Engl J Med. 1996; 334(14):873-877.
6. Palmer LS, Valcic M, Melman A, et al. Characterization of cyclic AMP accumulation in cultured human corpus cavernosum smooth muscle cells. J Urol. 1994;152(4):1308-1314.

7. Coombs PG, Heck M, Guhring P, Narus J, Mulhall JP. A review of outcomes of an intracavernosal injection therapy programme. BJU Int. 2012;110(11):1787-1791.

8. Sharlip ID. Evaluation and nonsurgical management of erectile dysfunction. Urol Clin North Am. 1998;25(4):647-659.

9. Porst $\mathrm{H}$, Burnett $\mathrm{A}$, Brock $\mathrm{G}$, et al. SOP conservative (medical and mechanical) treatment of erectile dysfunction. J Sex Med 2013;10:130-171.

10. Burnett AL, Nehra A, Breau RH et al: Erectile dysfunction: AUA guideline. J Urol 2018; 200: 633. 